\title{
KHARKIV ORGANIZATION OF THE CP (B) U: A STUDY OF THE FORMATION OF TOTALITARIAN PRINCIPLES OF INTERNAL PARTY LIFE (1920-1929)
}

\author{
Sergii Redka ${ }^{1}$, Nadiia Yaremchuk ${ }^{2}$, Tetiana Prykhodko ${ }^{3}$, Viktoriia Zolotoverkha ${ }^{4}$, Lesia Borzilo $^{5}$ \\ ${ }^{1}$ Department of Ukrainian Studies, School of Philosophy, V. N. Karazin Kharkiv National University, Kharkiv, Ukraine \\ redka5555@gmail.com \\ ORCID: https://orcid.org/0000-0001-5960-1968 \\ ${ }^{2}$ Kharkiv College of Trade and Economics, Kyiv National University of Trade and Economics, Kharkiv, Ukraine \\ kharkiv@htek.com.ua \\ ORCID: https://orcid.org/0000-0002-3992-4281 \\ ${ }^{3}$ Educational and methodical office, Cycle Commission of Economics, Management and Administration, Kharkiv College of Trade and \\ Economics, Kyiv National University of Trade and Economics, Kharkiv, Ukraine \\ tanya150378@ukr.net \\ ORCID: https://orcid.org/0000-0001-9679-8878 \\ ${ }^{4}$ Department of Economics, Management and Administration, Kharkiv College of Trade and Economics, Kyiv National University of \\ Trade and Economics, Kharkiv, Ukraine \\ vika chibisova@ukr.net \\ ORCID: https://orcid.org/0000-0002-2955-7705 \\ ${ }^{5}$ Kharkiv College of Trade and Economics, Kyiv National University of Trade and Economics, Kharkiv, Ukraine \\ lesyabozr28@gmail.com \\ ORCID: https://orcid.org/0000-0002-5181-9839
}

A R T I LE IN F O
Article history:
Received date 10.03 .2021
Accepted date 20.04 .2021
Published date 30.04 .2021
Section:
History
D O I

$10.21303 / 2313-8416.2021 .001789$

\section{KEYWORDS}

Kharkiv province totalitarian organization

Communist party

opposition

cells

ordinary party members

party leadership
ABSTRACT

The object of research: Kharkiv organization of the $\mathrm{CP}(\mathrm{b}) \mathrm{U}$ as a component of the institutions of the political system of Ukraine.

Investigated problem: The article depicts the process of transformation of the party organization of the Communist Party of the Bolsheviks of Ukraine of the Kharkiv province into a totalitarian organization.

Main scientific results: From the very beginning, Communist Party of the Bolsheviks of Ukraine of the Kharkiv province was created as an undemocratic organization. But in the early 1920 s, the internal party life of the party organization was characterized by some features of democracy. After the civil war, some communists demanded greater freedom of criticism, the initiative of the masses, and the fight against bureaucracy, but the opposition in the party organization, in contrast to the all-Union center, did not have an ideological platform. They were dissatisfied with the low financial status of ordinary communists and the privileges of the party nomenclature. The party apparatus resisted attempts to democratize party life, and ordinary communists were unable to resist this process. As a result, the party organization of Kharkiv region was transformed into a totalitarian organization, which was characterized by unanimity, intolerance of criticism, strict centralization, lack of election, powerlessness of ordinary members and uncontrolled power of the party apparatus.

Field of practical usage of research results: determined by suitability for use in the field of the modern state formation by politicians, parties, public organizations, state institutions, and the media.

Innovative technological product: on the basis of numerous archival materials, many of which are introduced into scientific circulation for the first time, a significant gap has been filled in the ideas about the process formation of totalitarian principles of internal party life at the regional level, namely in Kharkiv region.

Field of application of innovative technological product: the practice of forming, implementing and improving the system of state regulation by politic parties.

(C) The Author(s) 2021. This is an open access article under the Creative Commons CC BY license

\section{Introduction}

\section{1. The object of research}

Kharkiv organization of the CP (b) Uas a component of the institutions of the political system of Ukraine.

\section{2. ProblemDescription}

Political parties are important actors in the political process. The viability of civil society and the state is largely ensured by the presence of parties. The position and practical activity of 
parties are indicators of the democracy of society. An important condition for the parties to perform their functions in the field of political relations is to take into account the objective logic, harmonization of political interests of social groups, the ability to adjust their political course with changes in the social situation in the country. There are many political parties in the modern political field of Ukraine. But they do not meet modern democratic requirements.

Countless works were devoted to the activities of the Communist Party in Soviet historiography. The current level of historical knowledge suggests that the research of Soviet historians was limited by party postulates, although the actual side of this research has some value. Attempts to increase the amount of scientific knowledge about the history of the party were met with real opposition from the institutions of ideological control, any facts and events were considered from the point of view of the party's directives. Non-compliance with them in practice meant not only the impossibility of publishing research, but also their implementation. Thus, Soviet historiography contains significant factual material, which, with a critical approach, makes it possible to recreate the atmosphere that was created in Ukraine during the twenties.

The study of totalitarianism in the foreign scientific literature began almost simultaneously with its emergence. The object of study for foreign researchers was the political system created by the Bolsheviks. In the works of F. Hayek [1], C. Friedrich, Z. Brzezinski [2], K. Popper [3] a scientific analysis of certain aspects of totalitarianism was initiated, and the structure and functions of totalitarianism were studied. In this way, the theoretical foundations for its study were laid.

Some aspects of the formation of the totalitarian principles of the CP (B) U were considered during the years of independence. The monograph of V. Grechenko and O. Golovko, published in 2012, is devoted to the formation of a totalitarian party [4]. The work covers the process of creation and development of the Communist Party of Ukraine on the basis of significant factual material. The authors emphasize that the party organization of Ukraine did not actually have independence and was a branch of the Russian Communist Party. The monograph emphasizes that during the first half of the 1920s, the CP (B) U became a state party, eliminated other parties from political life, and concentrated power in the hands of a small ruling party center.

According to the organizational structure, it was centralized, with a fixed membership, according to the way of functioning - totalitarian. The party's policy did not depend on the opinions of ordinary members. It managed all the institutions of the political system. It was a party of illiterate, rather aggressive masses, diluted by corrupt officials and ideological fanatics. The authors conclude that the party became the basis of a totalitarian political system and created this system itself. It should be noted that research on the history of the Communist Party of Ukraine in the 1920s at the local level has never been created. Meanwhile, the diverse source base, represented by published and archival documents, as well as periodicals, makes it possible to do so.

\section{3. The solution to the proposed problem}

The solution to the problem is determined by the need to find the optimal model of political and socio-economic development of Ukraine. Realization of this is impossible without a comprehensive scientific understanding of national history both at the national level and at the level of individual regions.

Political parties have been and will remain important participants in the political process. The transformation of their network, the organization of intra-party life, the improvement of techniques and methods of influencing public policy must take place dynamically, determining the viability of civil society and the state.

The ways in which parties perform their functions depend on their nature, organizational structure and collective discussion of existing problems by its active members. The history of twentieth-century Ukraine shows how dangerous the usurpation of power by one political force or group of individuals can be.

The aim of research is to study the formation of totalitarian principles of intra-party life of the Kharkiv organization of the CP (b) U in 1920-1929, namely the need to show the process of transformation of the party organization into a totalitarian organization.

\section{Materials and methods}

The article is an attempt to study the process of formation of totalitarian features in the party organization of the Kharkiv province in the 1920s on the basis of modern methodological 
principles. The methodological basis of the article is a system of scientific principles, approaches and methods of cognition, aimed at a comprehensive study of socio-political phenomena, facts and events, objective reproduction and analysis of historical realities. The work is based on the fundamental principles of scientific knowledge ofhistoricism, objectivity, critical analysis, dialectics, systematics, comprehensiveness, alternatives, etc.

Maurice Duverger is considered the author of modern party theory. He formulated his key position: the essence of modern political parties is more fully and deeply revealed in its principles of construction; the party is organization based on a certain organizational structure; the nature of these basic structural units and the method of their integration into a single whole most significantly affects its socio-class composition and doctrinal unity; the effectiveness of the party and even the very principles and methods of this activity are most directly determined by the most stable characteristic of the party - its basic organizational structure [5].

In totalitarian parties, internal differences, sections, factions, deviations, currents are inconceivable -any "sectarianism" is intolerable here. The principle of uniformity is carried out in them strictly. Neither the majority nor the minority is there: the one who does not accept the party doctrine completely must leave the party. Opposition groups have only one choice: to choose between subordination and exclusion.

\section{Results}

Already in the first years of Soviet rule, the party organization of the Kharkiv province showed intolerance of dissent. Party members who imagined methods of building socialism differently from the Central Committee were expelled from the party, and the governing bodies and organization they elected were dissolved, although this contradicted the statute [6, p. 197].After the civil war, some communists demanded greater freedom of criticism, the initiative of the masses, and the fight against bureaucracy. They made attempts to democratize the party organization of the province. They were dissatisfied with the low financial status of ordinary communists and the privileges of the party nomenclature. The development of party democracy and the methods of building socialism for the party masses were not so topical [7, p. 24].

Manifestations of opposition among party members in the region have evolved. If in the early 1920 s the platform for speeches was primarily the party meeting, which raised the functioning of the party itself, then from the second half of the decadewere meetings in production units, unions, workers' dormitories, during which discussed mostly industrial and domestic problems.

Opposition activities in the Kharkiv region's party organization have not led to the unification of local party members around a clear ideological platform. This was facilitated by "purge". It served to protect themonolithic nature of its ranks. Due to the purge of the party, all those who did not agree with the policy pursued by the party leadership were expelled. Five purges were carried out in the Kharkiv provincial organization during the 1920s. They often had the character of a hasty campaign expelled from the party for theft, drunkenness, passivity, violation of party discipline, bureaucracy, use of official position and concealment of surplus grain, for refusal to enter the collective farm.

The purges created an atmosphere of uncertainty and instability in the party. The party members understood that they could be expelled from the party at any time and for contrived reasons, the formal criteria of which were not defined. The number of people expelled from the partycontributed to the creation of a state of insecurity. Up to $25 \%$ of party members were deprived of a party ticket in their cells [8].

The party's monopoly on power led to its monopoly on ideology. The country begins to be dominated by militant ignorance. Ideology becomes a means of persuading and uniting the country to build the future which has been outlined by the party scheme. This scheme was drawn up by the party leadership.It had to be accepted without discussion. The main thing was not to understand the practical issues facing the country, but to convince the citizens that the party itself knows where and how to move, and the people must follow the path it has indicated.

The ideological line of the party was declared the most correct, so the main thing was the struggle for the purity of this ideology. It is known that immediately after coming to power, the Bolsheviks imposed censorship, closed newspapers and magazines that were critical of the new government. Therefore, the Communist Party controlled the press. The Kharkiv provincial party 
organization created and financed the body of the Kharkiv provincial committee, of the Kharkiv City Soviet, and of the provincial council of trade unions of the Proletary newspaper (later the Kharkiv Proletarian), and it also appointed editors-in-chief. Monopoly control over the press promoted propaganda that divided society, opposed the interests of some to the interests of others, aroused unworthy instincts, and was a weapon in the class struggle [9, p. 45]. This allowed to influence people, to make them more obedient.

Illiteracy, pressure on the opposition, lack of criticism and freedom of speech lead to the fact that the ideology of the party was perceived in the cells as a dogma and was reduced to a few simple principles and a set of practical recipes. Only the Central Committee could determine whether certain theoretical attitudes corresponded to Lenin's teachings. Anyone who has not fully accepted the party's doctrine must leave the party. Opposition groups had a choice between repentance or exclusion. Leninism became a real means of fighting the opposition immediately after Lenin's death.

The system of apparatus terror did not stop only at the so-called ideological biases, real or imaginary, but inevitably extended to the entire life and activities of the organization. The party's control over its members reached the point that it tried to interfere even in private life. The party organization of the province regulated life: how communists should dress, forbade certain dances, interfered in family life and the upbringing of children, gave permission to enter universities [10, p. 63]. But the regulation was selective. Despite the myth of honest and selfless communists, the party nomenclature allowed itself surpluses in everyday life. Selective responsibility was also manifested in the commission of crimes. If the crime was committed by an ordinary communist, it was punished. Party leaders could not be punished.Themoral decayin the party organization was evidenced by the significant spread of drunkenness and sexually transmitted diseases.

Despite the fact that the party organization represented the capital region, the majority of communists in the cells were illiterate [11, p. 24].A large number of such party members created opportunities to manipulate their consciousness.

Personnel policy also contributed to the cohesion of the party organization in the Kharkiv region. The communists faced tasks that required clear and precise execution of orders from the governing bodies. Free elections did not promote that. Election from top to bottom, declared in the party's charter, was absent. Initially, this was due to the fact that there were practically no party cells in Ukraine and there was no one to choose from. With the increase in the number of party organizations in Ukraine and the Kharkiv province, elections at all levels were never introduced. Governing bodies were recommended, nominated, approved, and even appointed and removed from all positions in the party, and subordinates had to formally vote for the proposed candidate. In the early 1920s, when party bodies were being formed, the provincial committee appointed on party positions in party committees at all levels, sometimes even to rural cells. He also directed the work of councils, trade unions and the Komsomol in the province. Provincial committee sometimes interfered in the work of even village councils and grassroots trade unions and Komsomol organizations. Since 1925, when an extensive system of party organizations, councils, trade unions and Komsomol cells was established and the administrative division changed to village council district - county, district committees had all the power within their district to the level of the district committee. District committees managed the work of local party cells. The analysis of party documents of Kharkiv region eloquently confirms this. Elections in the party were held, but they were held formally, their result was decided in advance [12, p. 6].

The party apparatus consolidated, it felt its power and authority andreceived privileges. The apparatus has become an effective force that can neutralize the opposition and implement the decisions of the governing bodies. The nature of the resolutions adopted depended on the composition of the top leadership. The party workers saw their main task as implementing the will of the Central Committee, not the will of the entire party. The resolutions they adopted proposed to expand criticism, to developamateur activities in the party, to limit appointments, and to take into account the opinion of the minority. That is, the words about workers' democracy were just disguise. They all repeat the ideas proposed by the opposition. It was a kind of "hardware reception". The nomenclature spread the idea that it was necessary to raise the level of culture and education of party members and to improve the apparatus. It was said that the use of party democracy should depend on the degree of preparation of party members for it. Well-prepared political performances were held on the ground. Free discussion was allegedly held in the cells, but under the control of members of party committees. 
There was a constant process of transformation of the Kharkiv party organization into a totalitarian organization, which was characterized by unanimity, intolerance of criticism, rigid centralization, lack of elections, powerlessness of ordinary members and uncontrolled power of the party apparatus.

Attempts to build a dictatorship of the proletariat as the highest form of democracy led to the creation in the late 1920 s of a totalitarian party that completely enslaved the masses with its doctrine and interfered in private life. The party apparatus, relying on the monopoly of the spoken and printed word, appropriated the right to speak and act on behalf of the party and instead of the party.

\section{Discussion}

A considerable amount of literature has been published in this regard, but the interpretation of events has been presented within the framework of officially approved approaches and concepts. The literature was dominated by a unanimous positive assessment of the party's activity as a leading force in society [6]. After the creation of the Ukrainian state, the role of the CP (B) U was portrayed from a new point of view. But scientific research on the processes that took place in party cells at the regional level was not created. Therefore, on the basis of numerous archival materials, some of which are being introduced into scientific circulation for the first time, need study of the processes take place in party cells at the regional level, namely in the Kharkiv region.

It is necessary to study the processes that took place in local soviets, trade unions and Komsomol organizations.

\section{Conclusions}

The analysis of the formation of totalitarian principles of internal party life in the Kharkiv organization of the CP (B) U allowedto identify three stages in the development of this process. The first covers 1920 - the first half of 1923 - when the party organization had the possibility of relative freedom of expression.

The second stage took place in the second half of 1923 - the end of 1927, when party apparatushave the power in the provincial and district cells, butordinary communists retained the opportunity to express their views, but their opinion in final decisions is not taken.

The third stage - the end of 1927-1929 - is marked by a radical change in the atmosphere in party organizations at all levels, the dominance of hostile intolerance of dissent, large-scale actions of the apparatus to suppress any manifestations of intra-party democracy.

\section{References}

[1] Fridrich, A. (1944). Hayek The road to serfdom. Chicago, 266.

[2] Friedrich, C. J., Brzezinski, Z. K. (1956). Totalitarian Dictatorship and Autocracy. Cambridge, 346.

[3] Popper, K., Ryan, A., Gombrich, E. (2013). The Open Society and Its Enemies. Vol. 1. Princeton and Oxford, 261.

[4] Hrechenko, V., Holovko, O. (2012). Stanovlennia ta utvorennia totalitarnoi partii v Ukraini (1918-1941 rr.). Kharkiv, 402.

[5] Diuverzhe, M. (2002). Polytycheskye partyy. Moscow, 560.

[6] Ocherky istorii Kharkivskoi partiinoi orhanizatsii (1980). Kharkiv, 527.

[7] Radchenko, L., Redka, S., Rezenkina, N., Darmostuk, D., Islamova, A. (2019). Political struggle in the party organizations KP(b)U Kharkov province (1920-1922). ScienceRise, 5, 23-28. doi: http://doi.org/10.15587/2313-8416.2019.168790

[8] Proletaryi. Kak prokhodyt v uezdakh chystka (1921).

[9] Derzhavnyi arkhiv Kharkivskoi oblasti. (DAKhO) Fp.1. Op.1. Spr.1094. 206 ark. «Protokoly plenumu Kharkivskoho hubkomu. 08.01-21.12.1924».

[10] DAKhO. Fp.1. Op.1. Spr.42. 78 ark. «Protokoly zasidannia biuro hubkomu KP(b)U. 06.01.1920-26.12.1920».

[11] Biulleten VIII Vseukraynskoi konferentsyy KP(b)U 12-16 maia. 1924 h.: (Stenohramma) (1924). Kharkiv: Derzhvydav Ukrainy, 231.

[12] DAKhO. Fp.1. Op.1. Spr.5. 53 ark. «Zvit Kharkivskoho hubkomu KP(b)U. 22.12.1919-01.03.1920». 